\title{
Variation in photosynthesis and respiration in geographically distinct populations of two reef-building coral species
}

\author{
Karin E. Ulstrup ${ }^{1, *}$, Michael Kühl2,3, Madeleine J. H. van Oppen ${ }^{4}$, \\ Timothy F. Cooper ${ }^{5}$, Peter J. Ralph ${ }^{3}$ \\ ${ }^{1}$ DHI Water \& Environment, Level 2, 83 Havelock Street, West Perth, Western Australia 6005, Australia \\ ${ }^{2}$ Marine Biological Section, Department of Biology, University of Copenhagen, 3000 Helsingør, Denmark \\ ${ }^{3}$ Plant Functional Biology and Climate Change Cluster, University of Technology Sydney, Ultimo, New South Wales 2007, \\ Australia \\ ${ }^{4}$ Australian Institute of Marine Science, PMB 3 Townsville MC, Townsville, Queensland 4810, Australia \\ ${ }^{5}$ Australian Institute of Marine Science, UWA Oceans Institute (M096), 35 Stirling Highway, Crawley, \\ Western Australia 6009, Australia
}

\begin{abstract}
Studies of the regulation and importance of physiological processes such as coral photosynthesis and respiration on coral reefs require knowledge of spatio-temporal patterns of variability at different scales. Oxygen microelectrodes were used to measure photosynthesis and dark respiration of 2 corals, Pocillopora damicornis and Turbinaria reniformis, in the northern (Lizard Island) and central (Davies and Broadhurst Reefs) regions of the Great Barrier Reef (GBR) in winter and summer. Genetic characterisation of Symbiodinium revealed that $P$. damicornis hosted a single symbiont type (Symbiodinium C1) in both regions, whereas T. reniformis harboured 2 types, dependent on location. Colonies at Lizard Island harboured Symbiodinium D, whereas colonies at Davies Reef harboured Symbiodinium C2. Rates of gross photosynthesis were greater in the central than in the northern GBR in summer. A similar pattern was detected for dark respiration rates in T. reniformis. No seasonal change in either photosynthesis or dark respiration was evident in the northern GBR, possibly due to less annual variability in light conditions, and for T. reniformis, additionally the presence of Symbiodinium D. These results highlight that environmental conditions coupled with regional-scale distribution of Symbiodinium are likely to exert important influences on respiration and photosynthetic performance of reef-building corals.
\end{abstract}

KEY WORDS: Gross photosynthesis rate $\cdot \mathrm{O}_{2}$ microelectrode $\cdot$ Symbiodinium $\cdot$ Great Barrier Reef Resale or republication not permitted without written consent of the publisher

\section{INTRODUCTION}

The obligate association between Symbiodinium dinoflagellates and reef-building corals is maintained within a narrow temperature range (Hoegh-Guldberg 1999), where the productivity of Symbiodinium results in a net translocation of photosynthates to the host at irradiances higher than the compensation irradiance $\left(E_{\mathrm{C}}\right)$ (Muscatine 1990). At irradiances below $E_{\mathrm{C}}$, respiration exceeds production from photosynthesis, and light is, therefore, insufficient to cover the energetic demands of the holobiont. In highly oligotrophic environments, heterotrophic carbon and nutrient acquisition is considered limited for corals, which are likely to be adapted to a diet based mainly on the translocation of photosynthates from Symbiodinium. Environmental changes that cause increased metabolic demands, therefore, need to be paralleled by an increase in Symbiodinium production capacity to avoid constraining coral fitness. 
Photosynthesis and respiration, as measured by gas exchange, is, surprisingly, rarely measured for coral systems, despite the importance of understanding their metabolism. Further, we still know little in regards to how the photosynthesis:respiration ratio is regulated in reef systems on seasonal and large spatial scales. Photosynthesis and respiration quantified by $\mathrm{O}_{2}$ evolution of a coral community (Kayanne et al. 2005) as well as for individual coral species (Al-Sofyani \& Davies 1992, Nakamura et al. 2004) have previously been documented over seasonal scales. However, the findings in these studies were not consistent, suggesting that local environmental conditions, and possibly adaptive traits of the investigated holobionts, can exert important influences on metabolic processes.

Specific adaptive traits affecting metabolic processes, such as increased thermal tolerance, could arise from the type of Symbiodinium hosted by corals. Partitioning of genetically distinct Symbiodinium communities in conspecific coral populations has been found to correlate with latitude (Loh et al. 2001, Rodriguez-Lanetty et al. 2001, Savage et al. 2002, Ulstrup et al. 2006a) as well as with coral bleaching susceptibilities (Glynn et al. 2001, Berkelmans \& van Oppen 2006, Ulstrup et al. 2006a). This suggests that thermal tolerance is controlled by local environmental conditions that corals have adapted to (West \& Salm 2003) or that have caused the expression of distinct phenotypes. For instance, Ulstrup et al. (2006a) found that Turbinaria reniformis in the central region of the Great Barrier Reef (GBR) harboured predominantly Symbiodinium C, whereas conspecifics in the northern region of the GBR harboured predominantly Symbiodinium D. Although this pattern is specific to the type of coral examined, the occurrence of Symbiodinium D in this instance may provide a selective advantage for T. reniformis in the relatively warmer environment of the northern GBR.

While the interaction between Symbiodinium type and patterns of photosynthesis and respiration activity has been investigated over local-scale depth gradients (Mass et al. 2007), our understanding of such patterns of variation at larger spatial scales is currently limited. However, a recent study by Hennige et al. (2010) of the photosynthesis and respiration activity of corals across an environmental gradient of temperature, light and turbidity confirmed that metabolic rates were governed by acclimatisation to the local environment coupled with adaptation, which was manifested through a shift in Symbiodinium clade for one of their study species.

Winter and summer patterns of photosynthesis and dark respiration of geographically distinct coral populations that form symbiotic relationships with different Symbiodinium types have yet to be described. In the present study, we examined 2 species of reef-building corals with contrasting thermal tolerances and Symbiodinium type, Pocillopora damicornis (sensitive, Symbiodinium C1-specific) and Turbinaria reniformis (tolerant, spatial variation in Symbiodinium type harboured), during the austral summer and winter.

\section{MATERIALS AND METHODS}

Study area and sampling design. Photosynthesis and dark respiration were examined in Pocillopora damicornis and Turbinaria reniformis from mid-shelf reefs within the northern and central region of the GBR, Australia. In the northern region, colonies were collected at Lizard Island $\left(14^{\circ} 40.00^{\prime} \mathrm{S}, 145^{\circ} 27.48^{\prime} \mathrm{E}\right)$ in late July 2005 (winter) and January 2006 (summer). In the central region, T. reniformis was sampled at Davies Reef $\left(18^{\circ} 49.57^{\prime} \mathrm{S}, 147^{\circ} 37.76^{\prime} \mathrm{E}\right.$ ) in August 2005 (winter) and February 2006 (summer). P. damicornis was sampled at Broadhurst Reef $\left(18^{\circ} 52.27^{\prime} \mathrm{S}, 147^{\circ} 42.35^{\prime} \mathrm{E}\right)$ in winter and at the adjacent Davies Reef during the summer sampling. Lizard Island is located approximately $500 \mathrm{~km}$ north of Davies and Broadhurst Reefs, which are about $10 \mathrm{~km}$ apart (Fig. 1a).

Corals were sampled between 2 and $4 \mathrm{~m}$ below lowest astronomical tide (LAT) on each of 2 occasions spanning 2 wk: July or August 2005 and January or February 2006. Care was taken in targeting upright surfaces exposed to full ambient light and flow conditions, thereby minimising possible effects of microenvironmental gradients among the samples. Secchi depth data for the 2 locations were derived from a spatial model based on a comprehensive dataset comprising > 2000 observations across the GBR (http://eatlas.org.au). The daily photoperiod (sunrise to sunset) at Lizard Island and Davies Reef was obtained between May 2005 and April 2006 from Geoscience Australia (www.ga.gov.au) and used to determine the mean monthly photoperiod (Fig. 1b). Sea surface temperatures (SST) were obtained from the Australian Institute of Marine Science long-term temperature monitoring program (www.aims.gov.au/docs/data-centre/ seatemperatures.html). Average daily SST was acquired by temperature loggers (Dataflow Systems) deployed at 6 to $9 \mathrm{~m}$ depth on the reef slope at Lizard Island $\left(14^{\circ} 41.3^{\prime} \mathrm{S}, 145^{\circ} 26.6^{\prime} \mathrm{E}\right)$ and Davies Reef $\left(18^{\circ} 48.4^{\prime} \mathrm{S}, 147^{\circ} 40.1^{\prime} \mathrm{E}\right)$ (Fig. 1c).

Genetic characterisation of Symbiodinium. Symbiodinium in 4 colonies from each of the populations of Pocillopora damicornis and Turbinaria reniformis collected in winter were genetically characterised using the PCR-single stranded conformation polymorphism (SSCP) assay for the internal transcribed spacer region 1 (ITS1) as described in van Oppen et al. (2001). PCR products that resulted in different SSCP profiles 

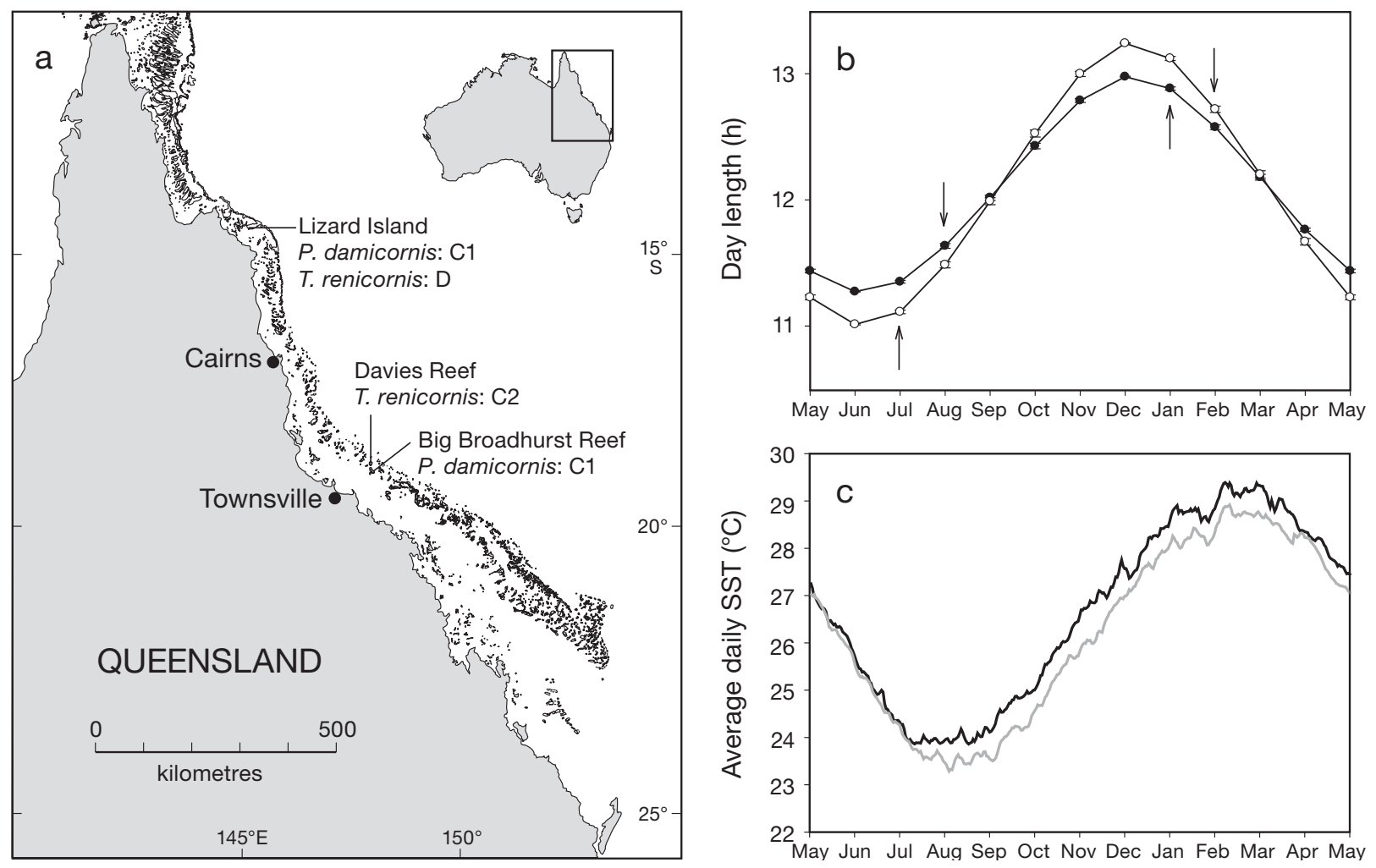

Fig. 1. (a) Map of the northeastern Australian coast showing sampling locations of Pocillopora damicornis and Turbinaria reniformis and their associated symbiont (Symbiodinium) type. (b) Annual variation in day length at Lizard Island (•) and Davies Reef (O) between May 2005 and April 2006. The data is derived from Geoscience Australia (www.ga.gov.au) and represents monthly averages $( \pm \mathrm{SE})$. Arrows indicate time of sampling at Lizard Island (upward-pointing arrows) and Davies Reef (downward-pointing arrows). (c) Average daily sea surface temperature (SST) for the reef slope (6 to $9 \mathrm{~m}$ depth) for each day (48 measurements per day) at Lizard Island (black) and Davies Reef (grey) between May 2005 and April 2006

were sequenced (Macrogen) and compared to existing sequences stored in GenBank (www.ncbi.nlm.nih.gov).

Photophysiological measurements. At each location, fragments of $4(n=4)$ colonies of both species were collected in the afternoon and placed at ambient seawater temperature (winter: $\sim 24.0 \pm 0.5^{\circ} \mathrm{C}$, summer: $\sim 28.5 \pm 0.5^{\circ} \mathrm{C}$ ) in a flow-through seawater tank overnight. During measurements conducted the following morning, the corals were held within a custom-built flow chamber $(25 \times 10 \times 10 \mathrm{~cm})$ at a controlled flow velocity of $\sim 1 \mathrm{~cm} \mathrm{~s}^{-1}$. $\mathrm{O}_{2}$ microelectrodes (Unisense) with a tip diameter of 25 to $50 \mu \mathrm{m}$ were linearly calibrated at experimental temperature and salinity from readings in air-saturated and $\mathrm{O}_{2}$-free seawater, respectively. The microsensor tip was positioned on the coenosarc surface of the coral through the centre of an LED ring which provided actinic light from oblique angles, thus minimising any self-shadowing effects on the measurements (Ulstrup et al. 2006b). Positioning of the microsensor was done while observing the sample with a dissecting microscope (Leica). Each of 8 actinic irradiances $(0,20,41,82,139,196,385,900 \mu \mathrm{mol}$ photons $\mathrm{m}^{-2} \mathrm{~s}^{-1}$ ) were applied for $10 \mathrm{~min}$. This was suffi- cient to reach steady-state $\mathrm{O}_{2}$ conditions, which is assumed for the photophysiological measurements (Ulstrup et al. 2006b).

A vertical microprofile of the $\mathrm{O}_{2}$ concentration gradient across the diffusive boundary layer was performed at stepwise increments of 10 to $20 \mu \mathrm{m}$ following incubation at each irradiance level. Area-specific net photosynthesis $\left(P_{\mathrm{n}}, \mathrm{nmol} \mathrm{O} \mathrm{cm}^{-2} \mathrm{~s}^{-1}\right)$ was calculated from the linear slope of the $\mathrm{O}_{2}$ concentration gradient in the diffusive boundary layer (DBL) using Fick's 1st law assuming a 1-dimensional diffusion geometry (Kühl et al. 1995, 1996). The dark microprofile conducted initially yielded a measure of area-specific respiration, $R_{\mathrm{D}}$, of the holobiont. Net photosynthesis measured at the maximum irradiance $\left(900 \mu \mathrm{mol}\right.$ photons $\left.\mathrm{m}^{-2} \mathrm{~s}^{-1}, P_{\mathrm{n} 900}\right)$ was chosen to calculate the photosynthesis:respiration ratio, $P_{\mathrm{n} 900}: R_{\mathrm{D}}$, as this represented an irradiance level where all samples were light saturated.

Upon completion of microprofile measurements at each irradiance level, the microsensor tip was repositioned at the coenosarc surface and a brief experimental light-dark shift was applied to allow calculation of the local volume-specific gross photosynthesis 
rate $\left(P_{\mathrm{g}}\right.$, $\left.\mathrm{nmol} \mathrm{O}_{2} \mathrm{~cm}^{-3} \mathrm{~s}^{-1}\right)$. The light-dark shift technique is based on the assumption that the immediate $\mathrm{O}_{2}$ depletion following the light-dark shift is equal to the gross photosynthetic $\mathrm{O}_{2}$ production during the previous light period (e.g. Kühl et al. 1996) in the measuring spot. The method yields the local volume-specific gross photosynthesis rate at a spatial resolution of $\sim 100 \mu \mathrm{m}$ and is independent of respiration (Revsbech \& Jørgensen 1983). This approach thus avoids problems associated with using dark respiration to calculate $P_{\mathrm{g}}$ given the effects of light on respiration rates (Edmunds \& Davies 1988, Kühl et al. 1996, Cooper et al. 2011). The light-dark shift technique seems to include $\mathrm{O}_{2}$ consumed by photorespiration, but not the Mehler reaction, which is tightly coupled to photosynthetic electron transport (Glud et al. 1992).

In principle, net fluxes of $\mathrm{O}_{2}$ can be subtracted from depth-integrated rates of gross-photosynthesis measurements done throughout the photic zone, yielding a measure of respiration in the light (Kühl et al. 1996). However, we only measured gross photosynthesis at the coenosarc tissue surface and could thus not do such calculations. The whole measuring sequence for each replicate took $\sim 2 \mathrm{~h}$ to complete. Collection of coral fragments was staggered such that the difference in acclimatisation period between replicates was no more than $2 \mathrm{~h}$. This was also done to minimise any potential effects of hysteresis and acclimation to the holding facility conditions (Anthony \& HoeghGuldberg 2003).

Statistical analysis. Changes in symbiont photosynthesis and holobiont dark respiration as a result of sampling time and differences in latitude were assessed by 2 -way ANOVA. The factors were Time and Location, with each considered as random and orthogonal. For all ANOVAs, Cochran's $C$ test was used to test for homogeneity of variances and data was transformed if necessary. Pooling procedures involving elimination of terms from the mean square estimates were done if a term was non-significant at $\mathrm{p}>0.25$ (Underwood 1997). Means for significant factors in the ANOVAs were compared using Student-Newman-Keuls (SNK) tests.

\section{RESULTS}

Genotyping analysis revealed that Pocillopora damicornis harboured Symbiodinium C1 irrespective of sampling location. In contrast, Turbinaria reniformis collected at Davies Reef harboured Symbiodinium C2 and at Lizard Island Symbiodinium D (Fig. 1a) sensu Ulstrup et al. (2006a). Light data for Lizard Island and Davies Reef showed that the optical properties of the column were comparable between the 2 locations with Secchi depths ranging from 13 to $16 \mathrm{~m}$ and 16 to $21 \mathrm{~m}$, respectively. The annual range in photoperiod was

Table 1. ANOVAs comparing photo-physiological parameters of Pocillopora damicornis and Turbinaria reniformis between times of sampling and location on the Great Barrier Reef (GBR). ${ }^{*}$ term eliminated at $\mathrm{p}>0.25$. Abbreviations: $P_{\text {g900 }}=$ gross photosynthesis rate $\left(\mathrm{nmol} \mathrm{O} \mathrm{cm}^{-3} \mathrm{~s}^{-1}\right), P_{\mathrm{n} 900}=$ net photosynthesis rate $\left(\mathrm{nmol} \mathrm{O} \mathrm{O}_{2} \mathrm{~cm}^{-2} \mathrm{~s}^{-1}\right.$ ) at $900 \mu \mathrm{mol}$ photons $\mathrm{m}^{-2} \mathrm{~s}^{-1}, R_{\mathrm{D}}=$ dark respiration rate $\left(\mathrm{nmol} \mathrm{O}_{2} \mathrm{~cm}^{-2} \mathrm{~s}^{-1}\right), \mathrm{NR}=$ northern region, $\mathrm{CR}=$ central region of the GBR

\begin{tabular}{|c|c|c|c|c|c|c|c|}
\hline Variate & $\begin{array}{l}\text { Source of } \\
\text { variation }\end{array}$ & $\mathrm{df}$ & MS & $F$ & $\mathrm{p}$ & \multicolumn{2}{|c|}{ Post-hoc tests } \\
\hline \multicolumn{8}{|c|}{ P. damicornis } \\
\hline \multirow[t]{4}{*}{$P_{\mathrm{g} 900}$} & Time & 1 & 40.8 & 0.17 & 0.7523 & & \\
\hline & Location & 1 & 228.09 & 0.94 & 0.5099 & & \\
\hline & Time $\times$ Loc & 1 & 242.66 & 5.79 & 0.0331 & Summer & $\mathrm{NR}<\mathrm{CR}$ \\
\hline & Residual & 12 & 41.91 & & & Winter & $\mathrm{NR}=\mathrm{CR}$ \\
\hline \multirow[t]{4}{*}{$P_{\mathrm{n} 900}$} & Time & 1 & 0.8789 & 3.95 & 0.0703 & & \\
\hline & Location & 1 & 0.3053 & 1.37 & 0.2644 & & \\
\hline & ${ }^{*}$ Time $\times$ Loc. & 1 & 0.0105 & 0.05 & 0.8317 & & \\
\hline & Residual & 12 & 0.2227 & & & & \\
\hline \multirow[t]{4}{*}{$R_{\mathrm{D}}$} & Time & 1 & 0.0176 & 0.15 & 0.7053 & & \\
\hline & Location & 1 & 0.1828 & 1.56 & 0.2357 & & \\
\hline & ${ }^{*}$ Time $\times$ Loc. & 1 & 0.077 & 0.66 & 0.4336 & & \\
\hline & Residual & 12 & 0.1173 & & & & \\
\hline \multirow[t]{4}{*}{$P_{\mathrm{n} 900}: R_{\mathrm{D}}$} & Time & 1 & 4.5382 & 4.23 & 0.0622 & & \\
\hline & Location & 1 & 0.4774 & 0.44 & 0.5175 & & \\
\hline & ${ }^{*}$ Time $\times$ Loc. & 1 & 0.0513 & 0.05 & 0.8306 & & \\
\hline & Residual & 12 & 1.0737 & & & & \\
\hline \multicolumn{8}{|c|}{ T. reniformis } \\
\hline \multirow{4}{*}{$P_{\mathrm{g} 900}$} & Time & 1 & 133.29 & 0.42 & 0.6352 & & \\
\hline & Location & 1 & 141.13 & 0.44 & 0.6269 & & \\
\hline & Time $\times$ Loc & 1 & 320.23 & 6.54 & 0.0251 & Summer & $\mathrm{NR}<\mathrm{CR}$ \\
\hline & Residual & 12 & 48.94 & & & Winter & $\mathrm{NR}=\mathrm{CR}$ \\
\hline \multirow[t]{4}{*}{$P_{\mathrm{n} 900}$} & Time & 1 & 2.5213 & 0.97 & 0.5056 & & \\
\hline & Location & 1 & 0.5105 & 0.2 & 0.735 & & \\
\hline & Time $\times$ Loc & 1 & 2.6117 & 4.52 & 0.0549 & & \\
\hline & Residual & 12 & 0.5778 & & & & \\
\hline \multirow[t]{4}{*}{$R_{\mathrm{D}}$} & Time & 1 & 0.6683 & 2.19 & 0.3784 & & \\
\hline & Location & 1 & 0.0663 & 0.22 & 0.7223 & & \\
\hline & Time $\times$ Loc & 1 & 0.3053 & 9.21 & 0.0104 & Summer & $\mathrm{NR}<\mathrm{CR}$ \\
\hline & Residual & 12 & 0.0332 & & & Winter & $\mathrm{NR}=\mathrm{CR}$ \\
\hline \multirow[t]{4}{*}{$P_{\mathrm{n} 900}: R_{\mathrm{D}}$} & Time & 1 & 0.0086 & 0.01 & 0.9301 & & \\
\hline & Location & 1 & 0.3164 & 0.3 & 0.5968 & & \\
\hline & ${ }^{*}$ Time $\times$ Loc & 1 & 0.273 & 0.25 & 0.6229 & & \\
\hline & Residual & 12 & 1.0715 & & & & \\
\hline
\end{tabular}


31 min greater at Davies Reef than at Lizard Island (Fig. 1b). The annual range in SST at Lizard Island was $\sim 5.5^{\circ} \mathrm{C}\left(23.9\right.$ to $\left.29.4^{\circ} \mathrm{C}\right)$ and $\sim 5.6^{\circ} \mathrm{C}\left(23.3\right.$ to $\left.28.9^{\circ} \mathrm{C}\right)$ at Davies Reef. Ambient average daily winter and summer SST at the time of measurements in both regions were $\sim 24^{\circ} \mathrm{C}$ and $\sim 28.5^{\circ} \mathrm{C}$, respectively (Fig. 1c).

The patterns of variation for gross photosynthesis rate at an irradiance of $900 \mu \mathrm{mol}$ photons $\mathrm{m}^{-2} \mathrm{~s}^{-1}\left(P_{\mathrm{g} 900}\right)$ were dominated by inconsistent variability between times of sampling and location for both species (Time $\times$ Location, Table 1). For example, in summer, the $P_{\mathrm{g} 900}$ of Pocillopora damicornis was higher at Davies Reef $\left(23.92 \pm 3.53 \mathrm{nmol} \mathrm{O} \mathrm{Cm}^{-3} \mathrm{~s}^{-1}\right)$ than at Lizard Island $\left(8.58 \pm 2.99 \mathrm{nmol} \mathrm{O}_{2} \mathrm{~cm}^{-3} \mathrm{~s}^{-1}\right)$, while there were no differences between regions in winter (Tables $1 \& 2$, Fig. 2). A similar pattern for $P_{\text {g900 }}$ occurred in Turbinaria reniformis (Tables 1 \& 2, Fig. 2). Rates of dark respiration in T. reniformis also varied inconsistently between times of sampling and locations (Time $\times$ Location, Table 1). In summer, the $R_{\mathrm{D}}$ of $T$. reniformis was higher at Davies Reef $\left(0.91 \pm 0.12 \mathrm{nmol} \mathrm{O}_{2} \mathrm{~cm}^{-2} \mathrm{~s}^{-1}\right)$ than at
Lizard Island $\left(0.51 \pm 0.12 \mathrm{nmol} \mathrm{O}_{2} \mathrm{~cm}^{-2} \mathrm{~s}^{-1}\right)$ but there were no differences between regions in winter (Fig. 3, Table 2). Although $P$. damicornis showed a trend for increased $P_{\text {n900 }}$ during summer in the central region of the GBR (Fig. 3) the $P_{\mathrm{n} 900}: R_{\mathrm{D}}$ ratio did not differ significantly between times of sampling or locations for either species (Tables 1 \& 2). From Fig. 3, it is also apparent that the change in $E_{\mathrm{c}}$ is greater between seasons for the central than for the northern region of the GBR.

\section{DISCUSSION}

Measurements of net photosynthesis and dark respiration measured in hospite are influenced by an unknown contribution of host respiration as well as the respiration of other organisms associated with the coral colony, such as bacteria as well as Symbiodinium. Therefore, our results from $\mathrm{O}_{2}$ microprofiling at the coral surface reflect the net production and dark respiration of the holobiont and not Symbiodinium alone. In

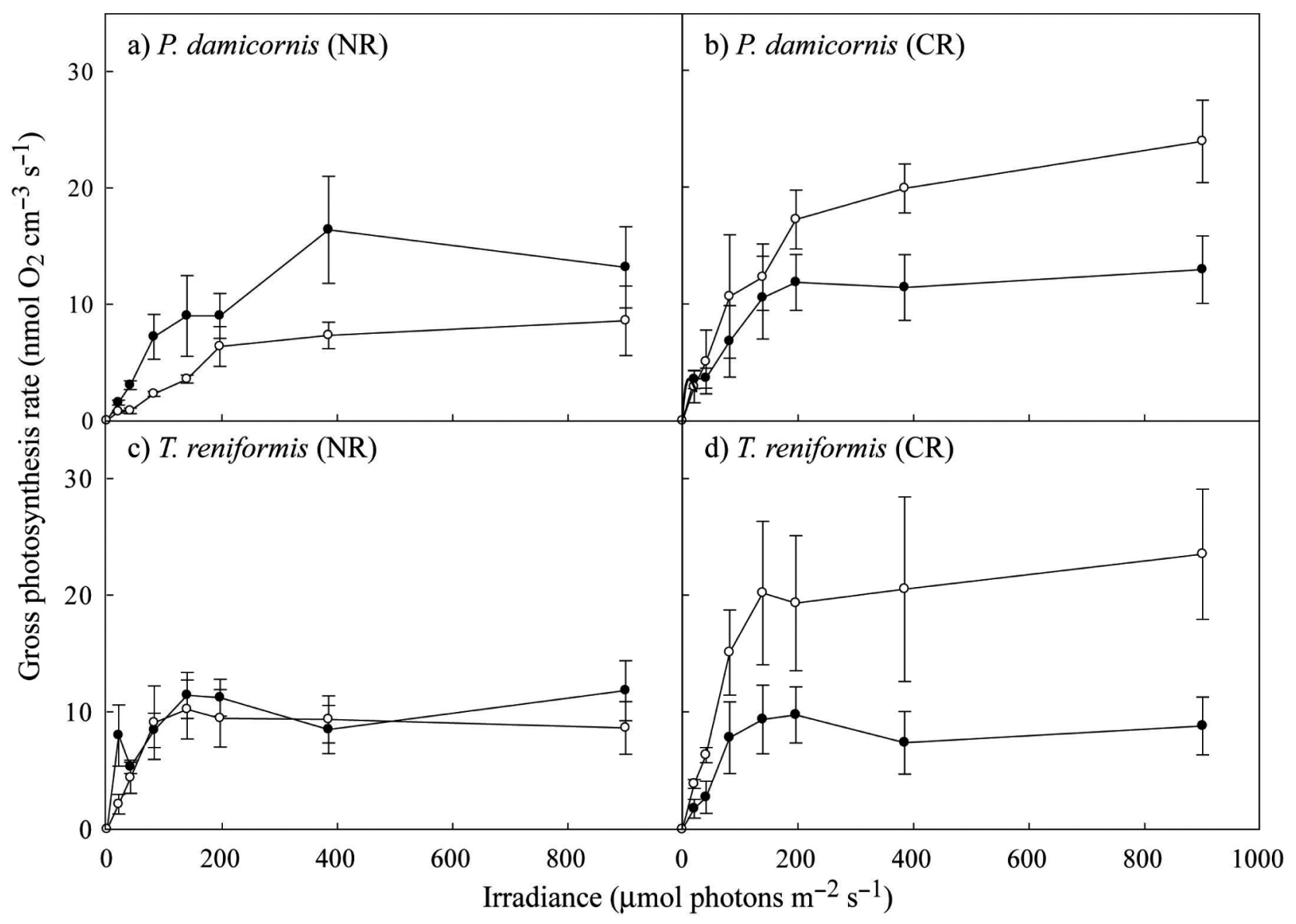

Fig. 2. Pocillopora damicornis and Turbinaria reniformis. Measurements of gross photosynthesis, $P_{\mathrm{g}}$, using the light-dark shift method at the coenosarc tissue surface of $(\mathrm{a}, \mathrm{b})$ P. damicornis and $(\mathrm{c}, \mathrm{d})$ T. reniformis in summer $(\mathrm{O})$ and winter $(\bullet)$ in $(\mathrm{a}, \mathrm{c})$ the northern $(\mathrm{NR})$ and $(\mathrm{b}, \mathrm{d})$ central regions $(\mathrm{CR})$ of the Great Barrier Reef. Values are mean $\pm \mathrm{SE}(\mathrm{n}=4)$ 


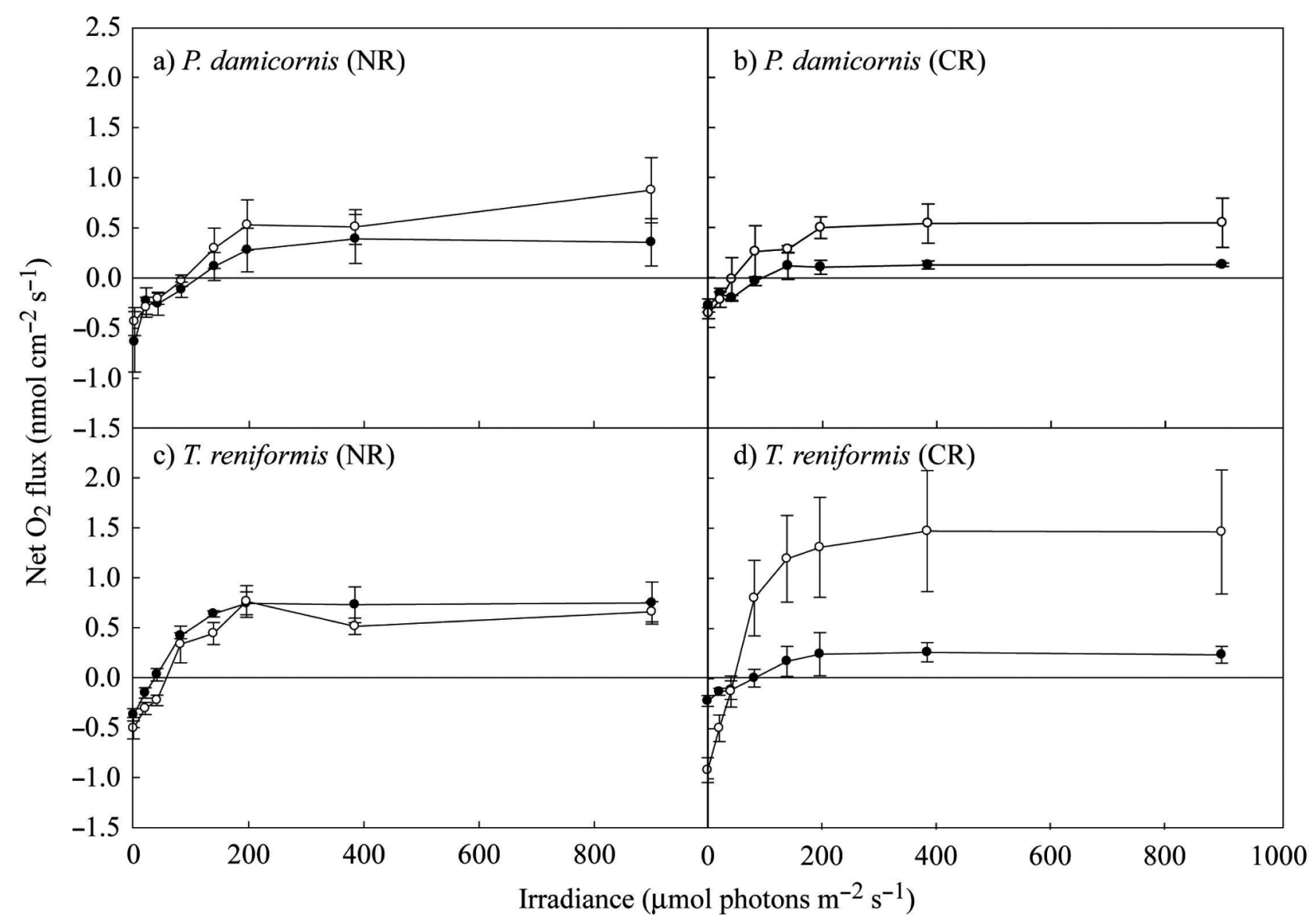

Fig. 3. Pocillopora damicornis and Turbinaria reniformis. Measurements of net photosynthesis, $P_{\mathrm{n}}$, as calculated from $\mathrm{O}_{2}$ microprofile measurements over the coenosarc tissue of $(\mathrm{a}, \mathrm{b})$ P. damicornis and $(\mathrm{c}, \mathrm{d})$ T. reniformis in summer $(\mathrm{O})$ and winter $(\bullet)$ in $(\mathrm{a}, \mathrm{c})$ the northern and $(b, d)$ central region of the Great Barrier Reef. Values are mean $\pm \mathrm{SE}(\mathrm{n}=4)$. The horizontal line indicates $\mathrm{O}_{2}$ flux and the irradiance at which the curve intersects the line is the compensation irradiance, $E_{\mathrm{c}}$

contrast, measurements of gross photosynthesis rates obtained from the light-dark shift method in this study relate to Symbiodinium production in hospite and are achieved independently of holobiont respiration measurements. This constitutes a technical advantage of microsensor measurements over the more conventional approach of using respirometry chambers, which does not allow the measurement of $P_{\mathrm{n}}$ and $P_{\mathrm{g}}$ independently (Kühl et al. 1995, Ulstrup et al. 2006b).
As a result, we found significant results for $P_{\text {g900 }}$ and not $P_{\text {n900, }}$ which is only possible if respiration rates differ with differing illumination intensities (Table 1, Cooper et al. 2011).

Our results suggest that photosynthesis and dark respiration of corals are influenced by a combination of environmental conditions as well as adaptive traits of the holobiont such as the Symbiodinium type hosted. Although beyond the scope of this study, host charac-

Table 2. Pocillopora damicornis and Turbinaria reniformis. $P_{\mathrm{g} 900}, P_{\mathrm{n} 900}, R_{\mathrm{D}}$ and $P_{\mathrm{n} 900}: R_{\mathrm{D}}$ from the northern and central region of the Great Barrier Reef in summer and winter. See Table 1 for abbreviations. Values are mean \pm SE $(n=4)$

\begin{tabular}{|c|c|c|c|c|c|c|c|c|}
\hline & \multicolumn{2}{|c|}{$P_{\mathrm{g} 900} \frac{}{\mathrm{CR}}$} & \multicolumn{2}{|c|}{$P_{\mathrm{n} 900}$} & $-R_{\mathrm{D}}$ & NR & \multicolumn{2}{|c|}{${ }_{\mathrm{CR}} P_{\mathrm{n} 900}: R_{\mathrm{D}} \frac{}{\mathrm{NR}}$} \\
\hline P. damicornis & & & & & & & & \\
\hline Summer & $23.92 \pm 3.53$ & $8.58 \pm 2.99$ & $0.55 \pm 0.25$ & $0.88 \pm 0.32$ & $0.36 \pm 0.05$ & $0.43 \pm 0.14$ & $1.79 \pm 0.99$ & $4.36 \pm 1.79$ \\
\hline Winter & $12.94 \pm 2.89$ & $13.17 \pm 3.49$ & $0.13 \pm 0.02$ & $0.36 \pm 0.24$ & $0.28 \pm 0.07$ & $0.64 \pm 0.30$ & $0.54 \pm 0.16$ & $0.87 \pm 0.40$ \\
\hline T. reniformis & & & & & & & & \\
\hline Summer & $23.52 \pm 5.59$ & $8.63 \pm 2.24$ & $1.46 \pm 0.62$ & $0.66 \pm 0.10$ & $0.91 \pm 0.12$ & $0.51 \pm 0.11$ & $1.57 \pm 0.69$ & $1.58 \pm 0.47$ \\
\hline Winter & $8.80 \pm 2.46$ & $11.80 \pm 2.56$ & $0.24 \pm 0.08$ & $0.75 \pm 0.21$ & $0.22 \pm 0.05$ & $0.37 \pm 0.06$ & $1.35 \pm 0.53$ & $1.89 \pm 0.31$ \\
\hline
\end{tabular}


teristics such as pigmentation and anti-oxidative enzymatic activity may also influence the photophysiological responses of Symbiodinium (Lesser et al. 1990, Gates \& Edmunds 1999, Salih et al. 2000). However, to our knowledge no regional-scale information on these host characteristics is available and this therefore warrants further investigation.

While corals in this study did not show any regionalscale differences in photosynthesis and dark respiration in winter, the differences observed in summer are likely to be affected by the contrasting environmental conditions between regions during this season. Lizard Island was $\sim 0.5^{\circ} \mathrm{C}$ warmer but had a shorter photoperiod during summer than coral reefs in our central study region. Although photophysiological responses to experimental changes in temperature are well known (e.g. Coles \& Jokiel 1977), the effect of spatial differences in irradiance are not. However, Mass et al. (2007) found that rates of photosynthesis and dark respiration decreased with increasing depth (and decreasing irradiance) over a $70 \mathrm{~m}$ depth gradient. A study by Cooper et al. (2011) confirmed this pattern but also found that a depth-related shift in Symbiodinium type in the coral Seriatopora hystrix over similar depths correlated with a non-linear response in the photosynthesis:respiration ratio. In addition to this, Symbiodinium cell densities may be dynamic over seasonal timescales, where densities are lower in summer than in winter (e.g. Fagoonee et al. 1999, Fitt et al. 2000). The effects of this on photosynthesis and dark respiration are, however, not easily interpreted as lowered densities may be paralleled by an increase in chlorophyll content per Symbiodinium cell (Brown et al. 1999, Cooper et al. 2008) as well as changes in host tissue biomass (Fitt et al. 2000), and are also likely to depend on the relative difference in environmental conditions among seasons.

The distribution pattern of Symbiodinium is likely to also influence the differences in photosynthesis and dark respiration observed between species, as Symbiodinium $\mathrm{D}$ in some associations has shown improved thermal tolerance compared to Symbiodinium C (e.g. Glynn et al. 2001, Berkelmans \& van Oppen 2006). We hypothesize that the occurrence of Symbiodinium D in Turbinaria reniformis at Lizard Island is an adaptive response to the higher temperature regime at this site compared with Davies Reef (Ulstrup et al. 2006a). In contrast, the summer increase in dark respiration, and hence higher metabolic cost, of T. reniformis in the central region could reflect lower tolerance to increased temperature (Coles \& Jokiel 1977), and possibly irradiance, of the association with Symbiodinium C2. The association between Pocillopora damicornis and Symbiodinium $\mathrm{C} 1$ was stable with respect to dark respiration across both spatial and temporal scales under non- bleaching conditions. The specificity of the association may, however, come at a cost during bleaching conditions, as a previous study demonstrated greater bleaching sensitivity of $P$. damicornis compared to $T$. reniformis irrespective of location (Ulstrup et al. 2006a).

In summary, these results suggest that local environmental conditions, as well as the Symbiodinium type involved in the coral-algal symbiosis are likely to exert important influences on photosynthetic performance and dark respiration of reef-building corals. We showed that temporal changes in photosynthesis and dark respiration were most pronounced in the central GBR. This is possibly due to greater seasonal variability in irradiance as well as adaptive traits of the holobionts investigated, such as the sensitivity of the association between Turbinaria reniformis and Symbiodinium C2 to summer conditions. Future studies should aim to determine the relative contribution of environmental controls, such as irradiance and temperature, and the effects of different Symbiodinium genotypes, on rates of photosynthesis and respiration.

Acknowledgements. This study was supported by funding from the Crown Prince Frederiks Foundation, Denmark (KEU), the Danish Natural Science Research Council (MK), the Australian Research Council and the Australian Institute of Marine Science. We thank volunteers who assisted with field work. The research was conducted under GBRMPA permit number G04/12776.1.

\section{LITERATURE CITED}

Al-Sofyani A, Davies PS (1992) Seasonal variation in production and respiration of red sea corals. Proc 7th Int Coral Reef Symp, Guam. University of Guam Press, Mangilao, p 351-357

Anthony KRN, Hoegh-Guldberg O (2003) Variation in coral photosynthesis, respiration and growth characteristics in contrasting light microhabitats: an analogue to plants in forest gaps and understoreys? Funct Ecol 17:246-259

> Berkelmans R, van Oppen MJH (2006) The role of zooxanthellae in the thermal tolerance of corals: a 'nugget of hope' for coral reefs in an era of climate change. Proc Biol Sci 273:2305-2312

Brown BE, Dunne RP, Ambarsari I, Le Tissier MDA, Satapoomin U (1999) Seasonal fluctuations in environmental factors and variations in symbiotic algae and chlorophyll pigments in four indo-pacific coral species. Mar Ecol Prog Ser 191:53-69

Coles SL, Jokiel PL (1977) Effects of temperature on photosynthesis and respiration in hermatypic corals. Mar Biol 43:209-216

Cooper TF, Ridd PV, Ulstrup KE, Humphrey C, Slivkoff M, Fabricius KE (2008) Temporal dynamics in coral bioindicators for water quality on coastal coral reefs of the great barrier reef. Mar Freshw Res 59:703-716

Cooper TF, Ulstrup KE, Dandan SS, Heyward A, and others (2011) Niche specialisation of reef-building corals in the mesophotic zone: metabolic trade-offs between divergent Symbiodinium types. Proc Biol Sci 278:1840-1850 
Edmunds PJ, Spencer Davies P (1988) Post-illumination stimulation of respiration rate in the coral Porites porites. Coral Reefs 7:7-9

Fagoonee I, Wilson HB, Hassell MP, Turner JR (1999) The dynamics of zooxanthellae populations: a long-term study in the field. Science 283:843-845

Fitt WK, McFarland FK, Warner ME, Chilcoat GC (2000) Seasonal patterns of tissue biomass and densities of symbiotic dinoflagellates in reef corals and relation to coral bleaching. Limnol Oceanogr 45:677-685

Gates RD, Edmunds PJ (1999) The physiological mechanisms of acclimatization in tropical reef corals. Am Zool 39:30-43

> Glud RN, Ramsmg NB, Revsbech NP (1992) Photosynthesis and photosynthesis-coupled respiration in natural biofilms measured by use of oxygen microsensors. J Phycol 28:51-60

Glynn PW, Mate JL, Baker AC, Calderon MO (2001) Coral bleaching and mortality in Panama and Ecuador during the 1997-1998 El Nino-Southern Oscillation event: Spatial/temporal patterns and comparisons with the 1982-1983 event. Bull Mar Sci 69:79-109

> Hennige SJ, Smith DJ, Walsh SJ, McGinley MP, Warner ME, Suggett DJ (2010) Acclimation and adaptation of scleractinian coral communities along environmental gradients within an Indonesian reef system. J Exp Mar Biol Ecol 391: 143-152

Hoegh-Guldberg O (1999) Climate change, coral bleaching and the future of the world's coral reefs. Mar Freshw Res 50:839-866

Kayanne H, Hata H, Kudo S, Yamano H and others (2005) Seasonal and bleaching-induced changes in coral reef metabolism and $\mathrm{CO}_{2}$ flux. Global Biogeochem Cycles 19: GB3015 doi:10.1029/2004GB002400

Kühl M, Cohen Y, Dalsgaard T, Jorgensen BB, Revsbech NP (1995) Microenvironment and photosynthesis of zooxanthellae in scleractinian corals studied with microsensors for $\mathrm{O}_{2}$, pH and light. Mar Ecol Prog Ser 117:159-172

Kühl M, Glud RN, Ploug H, Ramsing NB (1996) Microenvironmental control of photosynthesis and photosynthesiscoupled respiration in an epilithic cyanobacterial biofilm. J Phycol 32:799-812

Lesser MP, Stochaj WR, Tapley DW, Shick JM (1990) Bleaching in coral reef anthozoans: effects of irradiance, ultraviolet radiation, and temperature on the activities of protective enzymes against active oxygen. Coral Reefs 8:225-232

Loh WKW, Loi T, Carter D, Hoegh-Guldberg O (2001) Genetic variability of the symbiotic dinoflagellates from the wide ranging coral species Seriatopora hystrix and

Editorial responsibility: Hans Heinrich Janssen, Oldendorf/Luhe, Germany
Acropora longicyathus in the Indo-West Pacific. Mar Ecol Prog Ser 222:97-107

Mass T, Einbinder S, Brokovich E, Shashar N, Vago R, Erez J, Dubinsky Z (2007) Photoacclimation of Stylophora pistillata to light extremes: metabolism and calcification. Mar Ecol Prog Ser 334:93-102

Muscatine L (1990) The role of symbiotic algae in carbon and energy flux in coral reefs. In: Dubinsky Z (ed) Coral reefs, ecosystems of the world, Vol 25. Elsevier, Amsterdam, p 75-87

Nakamura E, Yokohama Y, Tanaka J (2004) Photosynthetic activity of a temperate coral Acropora pruinosa (Scleractinia, Anthozoa) with symbiotic algae in Japan. Phycol Res 52:38-44

Revsbech NP, Jørgensen BB (1983) Photosynthesis of benthic microflora measured with high spatial resolution by the oxygen microprofile method: capabilities and limitations of the method. Limnol Oceanogr 28:749-756

Rodriguez-Lanetty M, Loh W, Carter D, Hoegh-Guldberg O (2001) Latitudinal variability in symbiont specificity within the widespread scleractinian coral Plesiastrea versipora. Mar Biol 138:1175-1181

Salih A, Larkum A, Cox G, Kühl M, Hoegh-Guldberg O (2000) Fluorescent pigments in corals are photoprotective. Nature 408:850-853

Savage AM, Trapido-Rosenthal H, Douglas AE (2002) On the functional significance of molecular variation in Symbiodinium, the symbiotic algae of Cnidaria: photosynthetic response to irradiance. Mar Ecol Prog Ser 244:27-37

Ulstrup KE, Berkelmans R, Ralph PJ, van Oppen MJH (2006a) Variation in bleaching sensitivity of two coral species across a latitudinal gradient on the Great Barrier Reef: the role of zooxanthellae. Mar Ecol Prog Ser 314:135-148

Ulstrup KE, Ralph PJ, Larkum AWD, Kühl M (2006b) Intracolonial variability in light acclimation of zooxanthellae in coral tissues of Pocillopora damicornis. Mar Biol 149: 1325-1335

Underwood AJ (1997) Experiments in ecology: their logical design and interpretation using analysis of variance. Cambridge University Press

van Oppen MJH, Palstra FP, Piquet AMT, Miller DJ (2001) Patterns of coral-dinoflagellate associations in Acropora: Significance of local availability and physiology of Symbiodinium strains and host-symbiont selectivity. Proc Biol Sci 268:1759-1767

West JM, Salm RV (2003) Resistance and resilience to coral bleaching: Implications for coral reef conservation and management. Conserv Biol 17:956-967

Submitted: September 20, 2010; Accepted: March 16, 2011 Proofs received from author(s): May 13, 2011 